\title{
KECANDUAN INTERNET TERHADAP KETERAMPILAN SOSIAL DI ERA GENERASI MILENIAL
}

\author{
Sari Wardani Simarmata ${ }^{1}$ Yulia Citra ${ }^{2}$ \\ Program Studi Bimbingan dan Konseling STKIP Budidaya \\ sari.sarwa24@gmail.com
}

\begin{abstract}
Excessive use of the internet has a negative impact on social, communication and academic skills. Indirectly the internet can be a means for individuals who have low social skills will choose online interaction rather than direct interaction. This study aims to determine the effect of internet addiction on the social skills of millennial generation of class X SMK Putra Jaya Stabat Academic Year 2019/2020. This type of research used in this research is descriptive quantitative research. The population in this study were 39 students with a sample of 39 students. Data analysis using simple regression analysis, with normal and homogeneous data. After analyzing the results obtained $r$ count 0.239 <rtable 0.308 then in this case Ho was accepted and $H$ a was rejected based on this matter it can be concluded that there is no influence of internet addiction on the social skills of the millennial generation of grade X students of Putra Jaya Stabat 2019/2020 Academic Year
\end{abstract}

Keywords:Internet Addiction, Social Skill

\begin{abstract}
ABSTRAK
Penggunaan internet secara berlebihan memiliki dampak negatif dalam keterampilan sosial, komunikasi dan akademik. Secara tidak langsung internet dapat menjadi sarana bagi individu yang memiliki keterampilan sosial yang rendah akan memilih interaksi secara online daripada interaksi secara langsung. Penelitian ini bertujuan untuk mengetahui pengaruh kecanduan internet terhadap keterampilan sosial generasi milenial siswa kelas X SMK Putra Jaya Stabat Tahun Pelajaran 2019/2020. Jenis penelitian yang digunakan dalam penelitian ini adalah penelitian Kuantitatif deskriptif. Populasi dalam penelitian ini sebanyak 39 siswa dengan sampel sebanyak 39 orang siswa. Analisis data dengan menggunakan analisis regresi sederhana, dengan data normal dan homogen. Setelah dianalisis diperoleh hasil rhitung 0,239<rtabel 0,308 maka dalam hal ini Ho diterima dan Ha ditolak berdasarkan hal tersebut dapat disimpulan bahwa tidak ada pengaruh kecanduan internet terhadap keterampilan sosial generasi milenial siswa kelas X SMK Putra Jaya Stabat Tahun Pelajaran 2019/2020.
\end{abstract}

\section{Kata Kunci: Kecanduan Internet, Keterampilan Sosial}




\section{PENDAHULUAN}

Remaja merupakan aset sumber daya manusia yang mempunyai peranan yang vital sebagai generasi penerus bangsa dimasa yang akan datang. Masa remaja merupakan masa transisi dari masa anak-anak menuju masa dewasa dan identik dengan masa pencarian jati diri yang di tandai dengan peralihan perubahan fisik serta di ikuti dengan peralihan perubahan emosi atau kejiwaan yang masih sangat tidak stabil dan rentan dengan tindakan- tindakan negatif. Remaja merupakan generasi penerus bangsa yang harus mempunyai kedisiplinan baik, berakhlak mulia, menjaga emosi dengan baik, tangguh dan berkarakter baik. Selain itu juga harus dapat menyesuaikan diri dengan lingkungannya, dapat menghargai orang tua, guru, teman dan orangorang di sekitar.

Di tengah era milenial ini, banyak remaja yang tidak melakukan tugas perkembangannya dengan benar, banyak dari remaja generasi milenial sudah menyimpang dari tugasnya, maraknya budaya global dan gaya hidup pop culture, dianggap sebagai dampak globalisasi yang sudah tidak terbendung lagi. Generasi milenial adalah mereka yang dilahirkan antara tahun 1980 sampai dengan 2000. Salah satu ciri utama generasi milenial ditandai oleh peningkatan penggunaan dan keakraban dengan komunikasi, media, dan teknologi digital. Karena generasi milenial dibesarkan oleh kemajuan teknologi inilah yang menyebabkan generasi milenial terfokus ke teknologi digital dibandingkan dengan lingkungan sekitarnya.

Muetadin dalam Sanjaya (2012) mengemukakan bahwa "Salah satu tugas perkembangan yang harus dikuasai remaja yang berada dalam fase perkembangan masa remaja madya dan remaja akhir adalah memiliki ketrampilan sosial (social skill) untuk dapat menyesuaikan diri dengan kehidupan sehari-hari”. Keterampilan sosial, baik secara langsung maupun tidak membantu remaja untuk dapat menyesuaikan diri dengan standar harapan masyarakat dalam norma-norma yang berlaku disekelilingnya. Keterampilan sosial tersebut meliputi kemampuan berkomunikasi, menjalin hubungan dengan orang lain, menghargai diri sendiri dan orang lain, mendengarkan pendapat atau keluhan dari orang lain, memberi atau menerima feedback, memberi atau menerima kritik, bertindak sesuai norma dan aturan yang berlaku, dsb. Apabila keterampilan sosial dapat dikuasai oleh remaja tersebut maka ia akan mampu menyesuaikan diri dengan lingkungan sosialnya.

Keterampilan sosial menurut Syamsul B Thalib (2010) adalah kemampuan untuk mengatasi masalah-masalah yang timbul sebagai hasil dari interaksi dengan lingkungan serta dapat menyesuaikan diri dengan aturan dan norma yang berlaku. Keterampilan sosial meliputi kemampuan berkomunikasi, menjalin hubungan dengan orang lain, menghargai diri sendiri dan orang lain, mendengarkan pendapat atau keluhan dari orang lain, memberi atau menerima umpan balik (feedback), memberi dan menerima kritik, bertindak sesuai norma dan aturan yang berlaku dan sebagainya. Definisi keterampilan sosial menurut Comb dan Slaby dalam Sudarsih (2011) sebagai berikut :Keterampilan sosial merupakan kemampuan untuk berinteraksi dengan orang lain dalam satu konteks sosial dengan suatu cara yang spesifik yang secara sosial dapat diterima atau dinilai dan menguntungkan orang lain.

Keterampilan sosial merupakan kemampuan dalam berkomunikasi, menjalin hubungan dengan orang lain, mendengarkan pendapat atau keluhan dari orang lain, memberi atau menerima masukan seperti kritik, bertindak sesuai norma dan aturan yang berlaku. Faktor dari keterampilan sosial menurut hasil studi David dan Forsythe dalam Dwi istri (2016) yaitu (a) keluarga, Kepuasan psikis yang diperoleh anak dalam keluarga akan sangat menentukan bagaimana ia akan bereaksi terhadap lingkungan, (b) lingkungan, meliputi lingkungan fisik, sosial, kelurga primer dan keluarga sekunder, lingkungan sekolah serta masyarakat luas, (c) kepribadian, orang tua memberikan penanaman nilai- nilai yang menghargai harkat dan martabat orang lain tanpa mendasarkan pada hal-hal fisik seperti materi atau penampilan, (d) kemampuan menyesuaikan diri, anak sejak awal diajarkan untuk memahami dirinya sendiri agar dapat bereaksi secara wajar dan normatif. Menurut Eisler dalam Dwi istri (2016) ciri-ciri individu 
yang memiliki keterampilan sosial adalah : orang yang berani berbicara, memberikan pertimbang yang mendalam, memberikan respon yang lebih cepat, memberikan jawaban secara lengkap, mengutarakan bukti-bukti yang dapat menyakinkan orang lain, tidak mudah menyerah, menuntut hubungan timbal balik, serta lebih terbuka dalam mengekspresikan dirinya.

Menurut Retno (2013) Individu yang memiliki keterampilan sosial tinggi, cenderung diterima oleh lingkungannya, individu akan memiliki kepuasan dalam hidupnya, memiliki kepercayaan diri yang tinggi, memiliki harga diri, punya rasa humor, selalu optimis terhadap masa depannya, memiliki antusiasme, inisiatif dan semangat hidup tinggi, individu bebas untuk mengekspresikan pikiran dan perasaannya. Individu yang mengalami kesulitan dalam penyesuaian sosialnya, rasa percaya dirinya rendah, kurang bisa mempercayai orang lain, selalu diliputi oleh perasaan khawatir, tidak aman, ragu-ragu, konsep dirinya negatif, selalu merasa tidak puas terhadap kehidupannya, sulit untuk mengekspresikan pikiran dan perasaannya secara bebas, selalu merasa tertekan, dan merasa pesimis terhadap kehidupannya.

Fenomena yang terjadi sekarang ini banyak remaja yang memiliki keterampilan sosial yang rendah. Contohnya sebagian besar remaja lebih memilih curhat di sosial media untuk menuangkan perasaan yang sedang mereka rasakan dibandingkan dengan teman sebaya maupun orang tuanya. Sosial media berubah seperti buku harian atau diary, dimana user dapat mengeluhkan segala hal bahkan hal yang bersifat pribadi ke dalam akun sosial medianya. Misalnya mengeluhkan pelajaran yang sulit di sekolah, mengungkapkan rasa sedihnya karena patah hati, mengungkapkan kekesalan pada temannya dan sebagainya. Muculnya berbagai kicauan yang berisi tentang pengungkapan perasaan mungkin disebabkan oleh ketidakmampuan orang tersebut dalam mengungkapkan perasaannya secara langsung yang disebabkan oleh kurangnya keterampilan sosial yang dimiliki. Orang yang kurang memiliki keterampilan sosial akan lebih banyak menghabiskan waktunya di dunia maya dibandingkan dengan dunia nyata. Hal ini secara tidak langsung akan berdampak pada intensitas penggunaan sosial media yang dilakukan oleh orang tersebut. Intensitas merupakan tingkat keseringan individu dalam melakukan suatu kegiatan tertentu sesuai dengan perasaan, dimana perasaan senang terhadap suatu kegiatan tertentu akan mendorong individu untuk melakukan kegiatan tersebut berulang-ulang.

Penggunaan internet secara berlebihan memiliki dampak negatif dalam keterampilan sosial, komunikasi dan akademik. Tingkatpenggunaan internet yang tinggi akan mengakibatkan remaja merasa kesepiandari pada sebelumnya, Hal ini akan mempengaruhi keterampilan sosial padaremaja. Secara tidak langsung internet dapat menjadi sarana bagi individuyang memiliki keterampilan sosial yang rendah dan mengalami kesulitan dalammenjalin hubungan sosial secara face to face menjadi beralih ke dunia maya. Bagi individu yang memiliki keterampilan sosialyang rendah akan memilih interaksi secara online dari pada interaksi secaralangsung. Individu yang memiliki keterampilan sosial yang rendah cenderungmemiliki harga diri yang rendah, menilai percakapan biasa sulit untuk dilakukan,tidak nyaman ketika melakukan interaksi secara langsung sehingga dengan adanya internet mereka dapat berinteraksi dengan baikdengan orang lain, sedangkan individu dengan keterampilan sosial yang baik akan lebih mudah berinterakasi secara langsung maupun online.

\section{KAJIAN TEORI}

\section{A. Keterampilan Sosial}

Keterampilan sosial menurut Syamsul B Thalib (2010) adalah kemampuan untuk mengatasi masalah-masalah yang timbul sebagai hasil dari interaksi dengan lingkungan serta dapat menyesuaikan diri dengan aturan dan norma yang berlaku. Keterampilan sosial meliputi kemampuan berkomunikasi, menjalin hubungan dengan orang lain, menghargai diri sendiri dan orang lain, mendengarkan pendapat atau keluhan dari orang lain, memberi atau menerima umpan balik (feedback), memberi dan menerima kritik, bertindak sesuai norma dan aturan yang berlaku dan sebagainya.

Definisi keterampilan sosial menurut Comb dan Slaby dalam Sudarsih (2011) sebagai 
berikut :Keterampilan sosial merupakan kemampuan untuk berinteraksi dengan orang lain dalam satu konteks sosial dengan suatu cara yang spesifik yang secara sosial dapat diterima atau dinilai dan menguntungkan orang lain.

Berdasarkan penjelasan definisi di atas, keterampilan sosial adalah sekumpulan kemampuan atau kemampuan individu dalam berkomunikasi dan berinteraksi secara efektif yang dapat diterima dan dihargai oleh orang lain di lingkungannya, kemampuan untuk menyesuaikan diri dengan lingkungan, mengirim dan menerima pesan verbal maupun non verbal. Aspek-aspek keterampilan sosial menurut Rubin dan Martin (1994) :

\section{1. $\quad$ Self Disclosure}

Self Disclosure adalah kemampuan untuk membuka diri kepada orang lain melalui komunikasi.

2. Empathy

Aspek ini meliputi pengaruh reaksi emosi terhadap orang lain dan menghasilkan pemahaman untuk memahami perspektif orang lain.

\section{Social Relaxation}

Relaksasi sosial adalah kurangnya kecemasan atau ketakutan dalam interaksi sosial sehari-hari:

\section{Assertivenes}

Asertivitas adalah kemampuan dan kesediaan individu dalam menyampaikan perasaan-perasaan secara jelas dan dapat mempertahankan haknya secara tegas.

\section{Interaction management}

Manajemen interkasi merupakan kemampuan seseorang menangani cara berkomunikasi dalam kehidupan sehari-hari.

\section{Altercentrism}

Altercentrisme meliputi ketertarikan terhadap orang lain, perhatian terhadap apa yang mereka katakan dan bagaimana mereka mengatakan itu.

\section{Expressiveness}

Ekpresi merupakan kemampuan untuk berkomunikasi perasaan melalui perilaku non verbal seperti ekspresi wajah yang terlihat jelas, bahasa tubuh.

\section{Supportiveness}

Komunikasi suportif memperkuat yang lain dan ini menggambarkan, sementara, spontan, berorientasi terhadap pemecahan masalah.

\section{Immediacy}

Imediasi sering dikomunikasikan melalui perilaku nonverbal seperti berhadapan dengan orang secara langsung, bersikap terbuka, memiliki ekspresi wajah yang menyenangkan, menggunakan kontak mata langsung, serta perilaku nonverbal yang hangat, kedekatan dan afiliasi.

10. Environmental control

Mengontrol lingkungan berarti menunjukkan kemampuan seseorang untuk mencapai tujuan dan memenuhi kebutuhan.

\section{B. Kecanduan Internet}

Kecanduan internet adalah ketika seseorang terdorong untuk menghabiskan banyak waktu di internet, yang dapat mengganggu kehidupan seseorang seperti hubungan dengan orang lain, pekerjaan atau kesehatan.

Definisi kecanduan internet atau Internet addiction menurut Kimberlly S Young (1996) Kecanduan internet adalah pemakaian internet yang berlebihan yang mengganggu pola tidur, produktivitas kerja, rutinitas keseharian dan kehidupan sosial. Pecandu internet membuat internet menjadi prioritas dan lebih penting daripada keluarga, teman dan pekerjaan.

Dari penjelasan diatas, dapat disimpulkan bahwa kecanduan internet ialah kondisi pada kebiasaan yang sangat kuat dan tidak mampu lepas dari kebiasaan menggunakan internet, kurang mampu mengontrol diri sendiri untuk melakukan kegiatan tersebut.

\section{Aspek Kecanduan Internet}

Menurut Griffiths (2005) telah mencantumkan enam aspek untuk menentukan apakah individu sudah digolongkan sebagai pecandu internet. Aspek tersebut adalah sebagai berikut :

\section{Salience}

Hal ini terjadi ketika penggunaan internet menjadi aktivitas yang paling penting dalam kehidupan individu, mendominasi pikiran individu, perasaan merasa sangat butuh, dan perilaku.

\section{Mood modification}

Dimana terdapat perasaan senang dan tenang (seperti menghilangkan stress) saat perilaku kecanduan itu muncul.

\section{Tolerance}

Ini mengacu pada kebutuhan untuk meningkatkan jumlah waktu dalam menggunakan internet untuk kepuasan dan secara siginifikan mengurangi 
pengaruh dari penggunaan jumlah waktu yang sama pada penggunaan internet.

4.

Withdrawal symptoms

Gejala penarikan diri berkembang dalam beberapa hari selama satu bulan setelah pengurangan atau penghentian penggunaan internet dan mungkin hal ini menyebabkan distres atau gangguan sosial, personal atau pekerjaan.

\section{Conflict}

Konflik merupakan konflik yang terjadi antara individu yang teradiksi dengan orang di sekitar mereka, dengan pekerjaan, kehidupan sosial dan hobi atau dari individu itu sendiri dengan kegiatan tertentu.

$6 . \quad$ Relapse

Hal ini terjadi ketika individu kembali bermain internet, saat individu tersebut belum sembuh dari perilaku kecanduannya.

\section{METODE}

Jenis penelitian yang digunakan dalam penelitian ini adalah penelitian Kuantitatif deskriptif korelasional. Populasi dalam penelitian ini sebanyak 39 siswa kelas X SMK Putra Jaya Stabat. Teknik analisis data yang dilaksanakan dalam pengolahan data sebagai berikut: (1) Uji Normalitas, Pengujian normalitas dilakukan untuk mengetahui normal tidaknya suatu distribusi data. Uji normalitas dalam penelitian ini menggunakan metode KolmogorovSmirnov, (2) Uji Homogenitas Data, Pengujian homogenitass adalah mengenai sama tidaknya variansi-variansi dua buah distribusi atau lebih. Uji homogenitas digunakan untuk mengetahui homogen atau tidaknya antara variabel bebas dan variabel terikat, dan (3) Pengujuian Hipotesis, Melihat ada tidaknya kontribusi kecanduan internet terhadap keterampilan sosial, peneliti menggunakan teknik analisis regresi sederhana.

\section{HASIL}

Setelah data-data yang peneliti kumpulkan lengkap, maka selanjutnya peneliti mengadakan analisis ada atau tidaknya hubungan antara kecanduan internet (X) terhadap keterampilan sosial (Y), maka data-data yang diperoleh dianalisis dengan menggunakan bantuan perangkat komputer melalui program SPSS versi
25.0 .

\section{Uji Hipotesis}

Dalam pengujian hipotesis yang diuji koefisien korelasi $\left(r_{\text {hitung }}\right)$ dengan $r_{\text {tabel }}$ dan taraf nyata $\alpha=$ 0,05 .

Kriteria pengujian :

Terima Ha jika $r_{\text {hitung }}<r_{\text {tabel }}$ Terima Ho jika $r_{\text {hitung }}>$ $\mathrm{r}_{\text {tabel }}$

Dari hasil perhitungan di dapat $r_{\text {hitung }}$ sebesar 0,239 sedangkan $r_{\text {tabel }}$ pada taraf $5 \%$ sebesar 0,308 . Jadi disimpulkan bahwa nilai $\mathrm{r}_{\text {hitung }} 0,239$ < $\mathrm{r}_{\text {tabel }} 0,308$, sehingga Ho diterima, dan Ha ditolak. berdasarkan hal tersebut dapat disimpulan bahwa tidak ada pengaruh kecanduan internet terhadap keterampilan sosial generasi milenial siswa kelas $\mathrm{X}$ SMK Putra Jaya Stabat Tahun Pelajaran 2019/2020.

\section{SIMPULAN}

Dari hasil pembahasan penelitian dapat disimpulkan bahwa: (1) Dari hasil perhitungan diperoleh $r_{x y}$ sebesar 0.239 sedangkan pada $r_{\text {tabel }}$ dengan taraf 5\% sebesar 0.308 , jadi dilihat bahwa nilai $r_{x y}<r_{\text {tabel }}$. Oleh karena itu dapat simpulkan bahwa tidak ada pengaruh kecanduan internet terhadap keterampilan sosial pada Generasi Milenial Siswa kelas X SMK Putra Jaya Stabat tahun pelajaran 2019/2020, dan (2) Dari perhitungan uji $\mathrm{t}$, diperoleh nilai dengan angka kasar dari nilai $t_{\text {tabel }}$ adalah sebesar 2,026. Setelah diketahui bahwa nilai $t_{\text {hitung }}$ sebesar -1,498. Dapat juga dilihat bahwa signifikan 5\% menunjukkan 2,026, jadi nilai $r_{\text {hitung }}<r_{\text {tabel }}$ atau $-1,498<2,026$. jadi dapat diimpulkan bahwa Ho diterima dan $\mathrm{Ha}$ ditolak, maka hipotesis yang diajukan yaitu tidak terdapat pengaruh kecanduan internet terhadap keterampilan sosial pada Generasi Milenial Siswa kelas X SMK Putra Jaya Stabat tahun pelajaran 2019/2020.

Berdasarkan simpulan di atas, maka saran dapat diberikan kepada: (1) Siswa SMK Putra Jaya Stabat Diharapkan agar dapat melakukan penyesuaian sosial di lingkungannya, sehingga siswa disayangi, dihormati, dan dibutuhkan oranglain, (2) Guru BK Hendaknya menjalin kerjasama dengan orang tua dan mengawasi siswa dalam proses pendidikan dan perkembangan siswa, (3) Kepada orang tua agar memberi perhatian kepada anaknya untuk rajin belajar dan 
menegur bila tidak mengerjakan tugas rumah yang dibeikan oleh guru. Dan Orangtua hendaknya bersikap bijaksana dalam memahami kondisi siswa seperti masalah-masalah sosial yang dialami siswa, dan (4) Peneliti selanjutnya yang tertarik untuk memperkuat penelitian ini, agar dapat memperkaya penelitian ini dengan mengambil variabel lain yang diperkirakan berkontribusi terhadap keterampilan sosial.

\section{DAFTAR RUJUKAN}

Budiati, Indah dkk (2018) Profil generasi milenial. Jakarta : kementrian pemberdayaan perempuan dan anak.

Griffiths, M (2005) A 'components' model of addiction within a biopsychosocial framework. journal of subtance use. vol 10 no 4

Istri, Dwi (2016) hubungan antara kontrol diri dan keterampilan sosial dengan kecanduan internet pada siswa smk.Surakarta:Univ. Muhammadiyah Surakarta.

Sanjaya, Lastri (2012) Hubungan persepsi terhadap peran ayah dalam pengasuhan dengan keterampilan sosial pada remaja akhir.Malang : Univ. Muhammadiyah Malang.

Sari, Retno (2013) Perbedaan keterampilan sosial siswa akselerasi dengan reguler. Surakarta : Universitas Muhammadiyah.

Sudarsih,Wati (2011). keterampilan sosial siswa ADHDDI. universitas pendidikan indonesia.

Thalib, B Syamsul (2010) Psikologi Pendidikan

Young, S Kimberlly (1996) Internet Addiction: The Emergence OfA New Clinical Disorder Paper Presented At The 104th Annual. Canada : Meeting
Of

The

American

y Association. vol 1 no 3.

Psycholog

Yuwanto, L. (2010) Causes of Mobile Phone Addiction. Anima Indonesian psychological journal. vol 25 no 3 